\title{
POVERTY AND PUBLIC WORKS IN INDIA: SOME IMPLICATIONS FOR POLICY AND RESEARCH
}

\author{
G.B. Rodgers*
}

This paper discusses some of the general lessons which can be drawn from the author's study of public works and their effectiveness in reducing rural poverty in the Kosi area of Bihar. (Rodgers 1972).

Implications for Policy

The main implications for policy lie in two directions; firstly, in the integration of the concept of poverty into an objective framework; and secondly, in the evaluation of the role of public works programmes in the strategy for eliminating poverty. An adequate conceptualisation of poverty is a prerequisite to effective policy formulation - merely specifying an income as "the poverty line" will rarely suffice, and may be misleading. Poverty is a multivariate phenomenon, in which income, nutritional intake, non-food consumption, health, status, education and security are all relevant to its identification; and employment, occupation, wage levels, asset structure, demographic factors, labour organisation and a host of variables in the social framework all play a role in its generation. Moreover, there is a high level of interdependence among all these variables; identifying variables such as health and education interact with generating variables such as employment and organisation, and their interaction tends to perpetuate poverty because the relationships in the poverty complex form a set of interlocking vicious circles which make escape from the poverty situation difficult.

It is of great importance to realise that the effect of this system of interactions is to limit sharply the value of any given anti-poverty policy taken alone. If a policy operates on a single variable, the weight of multiple causation in the generation of poverty restricts benefits. If we take employment generation as an example, then poor health constrains the ability to work, low consumption levels reduce productivity, and status factors may

\footnotetext{
* Gerry Rodgers did postgraduate research at the University of Sussex, supervised by Leonard Joy (IDS). Field work was done in Kosi during 1969 and again during 1970-71.
} 
reduce participation. At the same time, assets will be little affected by increased income - marginal savings rates at low incomes are close to zero - status may be adverseley affected, and security will not be improved unless the permanence of the employment can be ensured. In almost all these relationships there is a negative reinforcement of poverty; and this pattern is repeated in the majority of policy contexts. But this situation could be turned to policy advantage, for with a wide-ranging attack on all aspects of poverty the reinforcement could well become positive. Policies which operate simultaneously throughout the poverty complex would be complementary, in that by reducing levels of poverty in one variable, negative effects on other poverty variables would also be reduced. There are therefore substantial gains from as broad an approach to poverty as possible; limited single policies such as employment generation, or attempts to influence status-linked factors (as in the policies for scheduled castes and tribes), can necessarily only achieve limited results.

A number of conclusions can be drawn from the Kosi study for the role of public works in the strategy for poverty. Firstly, it is possible to identify a number of ways in which public works could be made more relevant to poverty problems. Most fundamental of all, the poverty objective has to be made explicit. Recruitment has to take into account not only the efficiency of workers, but also their opportunity costs and income levels; this is not usually the case under a contract system. And if recruitment is to be directed specifically towards the poor, complementary policies in the fields of health and nutrition are essential. The wider interactions with the labour market have implications for planning and implementation which are equally substantial. Projects must be identified at the local level, and their predicted labour demands related to poverty at the village level, to the potential labour supply, and to alternative - i.e. usually agricultural - labour demands. A good deal of local knowledge is required if this is to be carried out effectively, but there can be no doubt that public works will be most effective if organised locally and moulded to fit the contours of the local labour markets. How then to avoid local vested interests from controlling the resources involved? The answer must lie in developing simplified, standardised project selection rules, which can be routinely applied locally, based on simplified models of economic and social benefit 
and cost for which relatively few parameters need to be estimated in each case, but which take into account both the poverty objective in the short term and the production objective in the long term. The need for such rules is obvious - unless public works have some long-term productive potential, it would be simpler and a good deal less exhausting to transfer resources directly from rich to poor. Indeed, it should be borne in mind that long-term bencfits should also compensate for the "disutility of work", quite apart from the alternative uses of the wage bill. If adequate, but simple rules could be strictly applied to each project, the scope for diversion of funds would be sharply reduced. Another major advantage of such decision criteria would be to aid in identifying the limits of useful public works. Clearly, productive public works are not unlimited in number, and marginal projects may have zero returns long before poverty reduction objectives are achieved.

Secondly, while public works may reduce poverty of some types, among some people, and in the short term, their potential for eliminating any form of poverty altogether is doubtful. The case studies from the Kosi area illustrate this point. There, employment was availabe only to a few, partly because of the preferences (often region, caste or culture-group specific) of contractors, and partly because, for reasons of poor health, inadequate nutrition, or social status, many of the "poor" could not or would not participate in the heavy earthwork which predominates in public works employment. Moreover, even among those prepared to do earthwork, the potential for adding to income was not large in relation to existing calorie deficits unless exceptionally high wages were paid. In terms of the multivariate conceptualisation of poverty presented above, the solution lies in formulating an effective overall strategy for poverty reduction, and such a strategy would require many policy instruments. If the ill and the old are to be assisted, employment generation is unlikely to be adequate and some form of social security system would be required. Health, nutrition, and sanitation are closely linked, and raising nutrition levels should be associated with more general health services. Where caste or other status variables are important factors in determining labour supply to earthwork, either work of a different status must be provided, or alternative mechanisms found for consumption transfers. The association of high household age dependency with low incomes 
rcquires spccial measures - the linking of wages to dependency for instance, or child feeding centres. Income and status questions affecting education would require specific policies - perhaps including compensation for the opportunity cost of school-age children. Problems of intra-household distribution of consumption might require family feeding programmes, or payments made directly to women. This list is long, and could easily be extended; and it can readily be secn that public works programmes, and indeed employment generation in general, can be only a part of a comprehensive anti-poverty package. And for this package to be large cnough to end the poverty problem in the foreseeable future, permanent alterations in the distributive mechanisms of the economy are required.

\section{Implications for Research}

The study has implications for research in several directions, but probably the most important area is to try to test at the macro-level what this research strongly suggests at the micro-level. My analysis of the effects of public works is based on a limited number of case studies in one part of India, and generalisation on the basis of these is at best tentative, at worst unjustified. There is an urgent need for a series of detailed micro-studies which investigate in other parts of India the questions raised at village and project level in the Kosi area, building up a profile of poverty and investigating the impact of public works thereon. Only on the basis of such a series of studies can a valid macro-policy be formulated.

A second area where research is required is in the conceptualisation of poverty. In this study a number of relationships have been identified, and their importance assessed both quantitatively and qualitatively. But much of this analysis takes only two variables at a time, which is less than adequate for the multivariate situation; and the joint interaction of all the variables in the poverty complex, which we have been able to consider only in rather general terms, needs much more detailed consideration.

A third important area of research is in the evolution of simplified decision rules to assist in project selection at the local level. The point here is to retain the essentials of economic appraisal, while remaining within the bounds of reasonable data availability, and at the same time giving the appropriate explicit weight to the poverty 
objective. A start has been made along these lines, with the evaluation of an irrigation scheme taken as an example ${ }^{1}$, but much more needs to be done to make such systems operational. Training of implementers would play a significant role here, and there is a need to develop administrative systems capable of undertaking evaluations in other than purely financial and political terms.

This leads us to a fourth question, namely the institutional and organisational aspects of public works. We have noted some of the arguments against the contract system, but in many respects departmentally organised projects can be equally bad. Even the organisation of labour recruitment can be crucial to the distribution of benefits. There is a need here to examine alternative institutional frame works for public works, in order to identify those which would best serve the poverty objective.

Fifthly, more detailed work is required to assess the limits to useful public works projects. The policy is dependent, at the macro-level, on there being schemes with productive potential available. But too little work has been done on assessing the overall scope for projects of this type, and examining the total level of benefit possible in relation to the size of the poverty question. There will come a point where direct transfers of consumption are a more efficient means of reducing poverty, and even if the political costs are high this is a fact which must be faced.

Sixthly, more work is required on the mechanisms underlying the operation of the labour market under labour withdrawal - the effects on wages, and on production and distribution patterns of withdrawing labour from agriculture for employment on public works are by no means obvious. In the Kosi area, a theory of nutritionally-based wage determination has been evolved and partly tested. (Forthcoming (a)). It would be of some interest to examine the influence of nutritional factors on labour markets in other areas. Moreover, it is of critical importance in assessing the likely impact of public works to understand the labour market situations in which they have to operate.

Finally, and most generally, more detailed analysis is required of the policies needed to eliminate all aspects of poverty. Here we have concentrated on public works, and considered other policies only

\footnotetext{
${ }^{1}$ See Poverty and Policy, op.cit.
} 
incidentally. But the main implication of the analysis is to demand a multi-facetted, co-ordinated attack on poverty. It is precisely such a strategy which does not exist; research is required into the ways in which different variables in the poverty complex react to different policy measures, and to identify the weakest links in the chain of relationships. Only when this has been undertaken can effective results be expected from a policy for poverty.

\section{References:}

G.B. Rodgers, 1972: Poverty and Policy: The Impact of Rural Public Works in the Kosi Area of Bihar, India. Unpublished D.Phil thesis, University of Sussex.

1973: "Effects of Public Works on Rural Poverty", Economic and Political Weckly, Annual Number, Vol. viii, Nos. 4-6.

Forthcoming (a): "Nutritionally-based Wage Determination in the Low-Income Labour Market".

Forthcoming (b): "A Conceptualisation of Indian Poverty", in the planned symposium of research papers on the Kosi Area", (Ed.) L. Joy.

Forthcoming (c): "Project Evaluation in Development Planning Rural Public Works and the Poverty Objective", in Kosi Symposium, (Ed.) L. Joy. 